\title{
Impact of Draw Solution Concentration on Forward Osmosis Process: A Simulation Study
}

\author{
Radwan Alfahel \\ ra1404482@qu.edu.qa \\ Department of Civil and Architectural Engineering, Qatar University, Doha, Qatar \\ MhdAmmar Hafiz \\ mh1201889@qu.edu.qa \\ Department of Civil and Architectural Engineering, Qatar University, Doha, Qatar \\ Alaa H. Hawari \\ a.hawari@qu.edu.qa \\ Department of Civil and Architectural Engineering, Qatar University, Doha, Qatar
}

\begin{abstract}
In this study, a simulation model was used to evaluate the performance of forward osmosis process. A solution of low salinity was used as the feed solution in forward osmosis to dilute saline solution (i.e. draw solution) for further desalination. The paper evaluated the effect of the draw solution concentration on the recovery rate and energy consumption in forward osmosis. It was found that increasing the concentration of draw solution increased the recovery rate. Also, while increasing concentration of draw solution, energy consumption decreased. The maximum recovery rate of $33 \%$ was achieved using $(0.5 \mathrm{M} \mathrm{NaCl})$ draw solution and a flow rate of $40000 \mathrm{~m} 3 /$ day. The specific power consumption was $0.21 \mathrm{kWh} / \mathrm{m} 3$.
\end{abstract}

Keywords: Forward osmosis; Feed solution; Recovery rate; Power consumption

\section{INTRODUCTION}

The availability of clean water was one of the sustainable development goals placed forward in the 2030 agenda of the United Nations (Lim et al., 2019). Nowadays, groundwater and seawater are the main sources of water for drinking and irrigation purposes. Membrane technologies have gained much attention for the desalination of seawater and brackish water due to their ability to generate clean water (Greenlee et al., 2009; Hafiz et al., 2019; Heijman et al., 2009; Misdan et al., 2012; Shaffer et al., 2012). Desalination of seawater is usually done using energy intensive processes (i.e., Multistage Flash (MSF) and Reverse Osmosis (RO)) (Elimelech \& Phillip, 2011). However, the desalination of wastewater and brackish groundwater consumes a lower amount of energy while using similar technologies. Therefore, low-pressure reverse osmosis and Nano Filtration (NF) have been proposed as convenient technologies for the desalination of brackish water (Phuntsho et al., 2013; Walha et al., 2007). Fouling is considered a major drawback for pressure-driven membrane technologies which increases the operating cost of the process (Guo et al., 2012). Consequently, forward osmosis has attracted more attention because it depends on the osmotic pressure of the draw and feed solution (Lutchmiah et al., 2014). Chen et al. (2017) evaluated the applicability of using the FO process for concentrating wastewater. It was done using 
pilot-scale forward osmosis, low strength municipal wastewater as the feed solution and $0.5 \mathrm{M} \mathrm{NaCl}$ as the draw solution. A spiral-wound membrane module was used to operate the system. 99.8\% COD rejection rate, $99.7 \%$ total phosphorus rejection rate and $67.8 \%$ of ammonium rejection rate were achieved with a flux of $6 \mathrm{LMH}$. Phuntsho et al. (2016) evaluated the performance of pilot scale forward osmosis - nano filtration plant which was operated for six months using brackish ground water from the coal mining activities. The study indicate that the hybrid system can produce water quality that meets irrigation standards. The FO feed brine failed to satisfy the discharge effluent standards due to the high concentrations of ammonium and sulfate.

This study investigates the effect of flow rate and draw solution concentration on the performance of forward osmosis process using a numerical simulation model. This was done by estimating the recovery rate and specific power consumption.

\section{METHODOLOGY}

In forward osmosis, the water flux depends on the osmotic pressure gradient. The osmotic pressure gradient can be estimated by calculating the difference of osmotic pressure between the feed and draw solutions. Therefore, the water flux in the FO process $\left(\mathrm{J}_{\mathrm{w}}\right)$ can be calculated using equation 1 (Altaee et al., 2016):

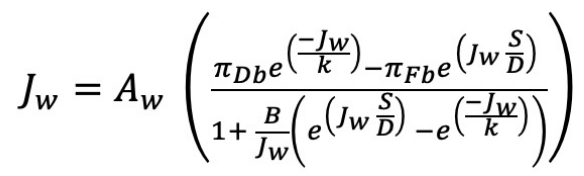

where, $\mathrm{A}_{\mathrm{w}}$ is the membrane permeability coefficient $\left(\mathrm{L} / \mathrm{m}^{2} \mathrm{~h}\right.$ bar $), \pi_{\mathrm{Db}}$ and $\pi_{\mathrm{Fb}}$ are the osmotic pressure of the bulk draw and feed solution, respectively (bar); $\mathrm{k}$ is the mass transfer coefficient $(\mathrm{m} / \mathrm{s})$; B is the solute permeability coefficient $\left(\mathrm{kg} / \mathrm{m}^{2} \mathrm{~h}\right)$; $\mathrm{S}$ is the membrane structure $(\mu \mathrm{m}), \mathrm{D}$ is the solute diffusion coefficient $\left(\mathrm{m}^{2} / \mathrm{s}\right)$. The specific power consumption in the FO process, Es, was estimated using equation 2 (Altaee et al., 2016):

$$
\text { Es }=\frac{1}{\left(36 * \eta * Q_{p}\right)}\left(P_{f} Q_{f-i n}+P_{D} Q_{D-i n}\right) .
$$

where, $Q_{\text {fin }}$ is the feed solution flow rate $\left(\mathrm{m}^{3} / \mathrm{h}\right), \mathrm{P}_{\mathrm{D}}$ is the draw solution feed pressure (bar) and $Q_{D-i n}$ is the draw solution flow rate to the FO membrane $\left(\mathrm{m}^{3} / \mathrm{h}\right)$. The recovery rate of the forward osmosis process is the ratio of permeate flow rate to the feed flow rate as shown in equation 3 (Altaee et al., 2016).

$$
\mathrm{R} \%=\frac{Q_{p}}{Q_{f}} \times 100 \%
$$

where, $Q_{p}$ is the permeate flow rate $\left(\mathrm{m}^{3} / \mathrm{h}\right), \mathrm{Q}_{\mathrm{f}}$ is the feed solution flow rate $\left(\mathrm{m}^{3} / \mathrm{h}\right)$.

\section{RESULTS AND DISCUSSION}

In the simulation study the concentration of the draw solution varied between 0.25 $\mathrm{M}$ and $0.5 \mathrm{M} \mathrm{NaCl}$ with an increase of $0.05 \mathrm{M}$ for each batch. The feed solution was $0.2 \mathrm{M} \mathrm{NaCl}$. The feed solution flowrate varied between $40,000 \mathrm{~m}^{3} /$ day and 100,000 $\mathrm{m}^{3} /$ day with an increase of $10,000 \mathrm{~m}^{3} /$ day for each batch. DS flowrate was kept at the same flowrate of the feed solution. The effect of draw solution concentration on the recovery rate is shown in Figure 1. The recovery rate was $8.5 \%$ using $0.25 \mathrm{M} \mathrm{NaCl}$ draw 
solution and FS flow rate of $100,000 \mathrm{~m}^{3} /$ day. As the concentration of DS increased to $0.5 \mathrm{M}$ the recovery rate increased to $19.5 \%$. This is due to the increase in the osmotic pressure gradient. The recovery rate was $29.5 \%$ using $0.5 \mathrm{M} \mathrm{NaCl}$ draw solution and FS flow rate of $50,000 \mathrm{~m}^{3} /$ day. Generally, the recovery rate increased as the concentration of draw solution increased. The minimum recovery rate was $8.5 \%$ using $0.25 \mathrm{M} \mathrm{NaCl}$ draw solution and FS flowrate of 40,000 $\mathrm{m}^{3} /$ day, because of the small osmotic pressure gradient between feed solution and draw solution.

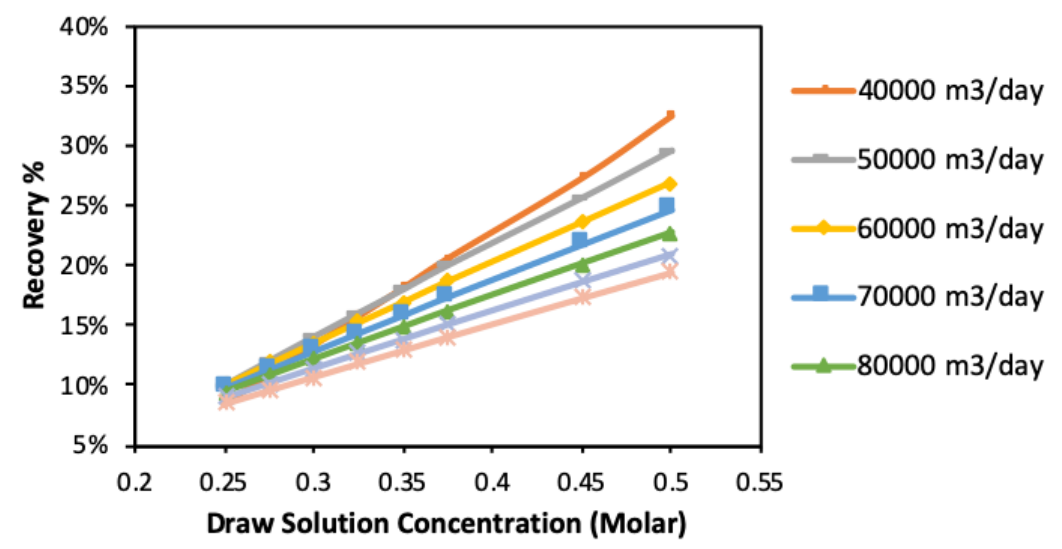

Figure 1: Recovery rate of forward osmosis using different FS flowrate and [0.25 - 0.5 $\mathrm{M}] \mathrm{NaCl}$ draw solution

The effect of flowrate and draw solution concentration on the specific energy consumption is shown in Figure 2. The maximum specific energy consumption was $0.82 \mathrm{kWh} / \mathrm{m}^{3}$ using $0.25 \mathrm{M} \mathrm{NaCl}$ draw solution and FS flowrate of $100,000 \mathrm{~m}^{3} /$ day. The minimum specific energy consumption was $0.21 \mathrm{kWh} / \mathrm{m}^{3}$ using $0.5 \mathrm{M} \mathrm{NaCl}$ draw solution and FS flow rate of 40,000 $\mathrm{m}^{3} /$ day. Generally, power consumption decreased as the FS concentration increased. The energy consumption decreased as the concentration of draw solution increased.

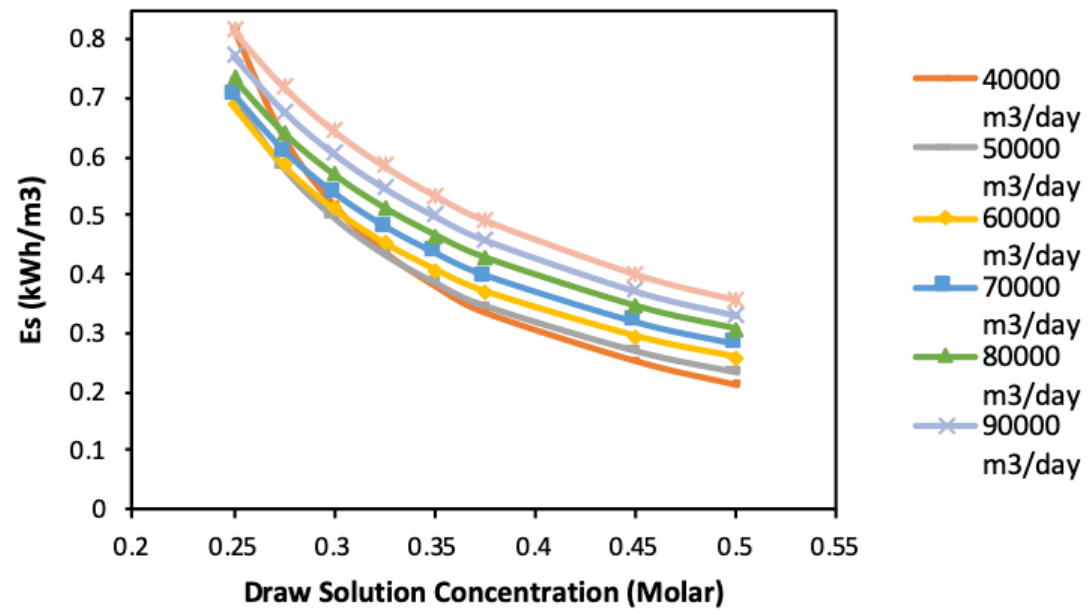

Figure 2: Energy consumption of forward osmosis using different FS flowrate and [0.25 $-0.5 \mathrm{M}] \mathrm{NaCl}$ draw solution 


\section{CONCLUSION}

The results reported in this study show that forward osmosis is a promising technology for desalination of saline water. Water recovery of forward osmosis can be enhanced by increasing the DS concentration. Also, the energy consumption can be reduced by increasing the DS concentration.

\section{ACKNOWLEDGMENTS}

This research is made possible by Graduate Sponsorship Research Award (GSRA6-10509-19021) from Qatar National Research Fund (QNRF). The statements made herein are solely the responsibility of the authors.

\section{REFERENCES}

Altaee, A., Millar, G. J., Sharif, A. O. \& Zaragoza, G. (2016). Forward osmosis process for supply of fertilizer solutions from seawater using a mixture of draw solutions. Desalination and Water Treatment, 57(58), 28025-28041.

Chen, Z., Luo, J., Wang, Y., Cao, W., Qi, B. \& Wan, Y. (2017). A novel membrane-based integrated process for fractionation and reclamation of dairy wastewater. Chemical Engineering Journal, 313, 1061-1070.

Elimelech, M. \& Phillip, W. A. (2011). The future of seawater desalination: Energy, technology, and the environment. Science, 333(6043), 712.

Greenlee, L. F., Lawler, D. F., Freeman, B. D., Marrot, B. \& Moulin, P. (2009). Reverse osmosis desalination: Water sources, technology, and today's challenges. Water Research, 43(9), 2317-2348.

Guo, W., Ngo, H. H. \& Li, J. (2012). A mini-review on membrane fouling. Bioresource Technology, 122, 27-34.

Hafiz, M. A., Hawari, A. H. \& Altaee, A. (2019). A hybrid forward osmosis/reverse osmosis process for the supply of fertilizing solution from treated wastewater. Journal of Water Process Engineering, 32, 100975.

Heijman, S. G. J., Guo, H., Li, S., van Dijk, J. C. \& Wessels, L. P. (2009). Zero liquid discharge: Heading for $99 \%$ recovery in nanofiltration and reverse osmosis. Desalination, 236(1), 357362.

Lim, S., Tran, V. H., Akther, N., Phuntsho, S. \& Shon, H. K. (2019). Defect-free outer-selective hollow fiber thin-film composite membranes for forward osmosis applications. Journal of Membrane Science, 586, 281-291.

Lutchmiah, K., Verliefde, A. R. D., Roest, K., Rietveld, L. C. \& Cornelissen, E. R. (2014). Forward osmosis for application in wastewater treatment: A review. Water Research, 58, 179-197.

Misdan, N., Lau, W. J. \& Ismail, A. F. (2012). Seawater Reverse Osmosis (SWRO) desalination by thin-film composite membrane-Current development, challenges and future prospects. Desalination, 287, 228-237.

Phuntsho, S., Hong, S., Elimelech, M. \& Shon, H. K. (2013). Forward osmosis desalination of brackish groundwater: Meeting water quality requirements for fertigation by integrating nanofiltration. Journal of Membrane Science, 436, 1-15.

Phuntsho, S., Kim, J. E., Johir, M. A. H., Hong, S., Li, Z., Ghaffour, N., Leiknes, T. \& Shon, H. K. (2016). Fertiliser drawn forward osmosis process: Pilot-scale desalination of mine impaired 
water for fertigation. Journal of Membrane Science, 508, 22-31.

Shaffer, D. L., Yip, N. Y., Gilron, J. \& Elimelech, M. (2012). Seawater desalination for agriculture by integrated forward and reverse osmosis: Improved product water quality for potentially less energy. Journal of Membrane Science, 415-416, 1-8.

Walha, K., Amar, R. B., Firdaous, L., Quéméneur, F. \& Jaouen, P. (2007). Brackish groundwater treatment by nano filtration, reverse osmosis and electrodialysis in Tunisia: performance and cost comparison. Desalination, 207(1), 95-106. 